CATALLAXY

Volume 4 Issue 1 June 2019

e-ISSN 2544-090X

C www.catallaxy.pl

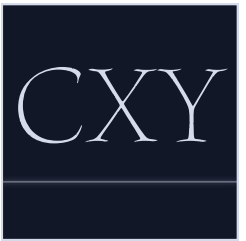

Oryginalny artykut naukowy

otrzymano: 10.06.2019 / zaakceptowano: 28.06.2019 / opublikowano online: 30.06 .2019

Pestkowski, A. (2019). Koopetycja jako strategia glokalizacji przedsiębiorstw w Polsce. Catallaxy, 4(1): 29-44. doi:10.24136/cxy.2019.005.

\title{
Koopetycja jako strategia glokalizacji przedsiębiorstw w Polsce
}

\author{
ANDRZEJ PESTKOWSKI \\ Uniwersytet Ekonomiczny we Wroctawiu, Wydział Zarzadzania, Informatyki i Finansów, Katedra Strategii i Metod \\ Zarzadzania, ul. Komandorska 118-120, 53-345 Wroctaw, Polska \\ ๑andrzej@pestkowski.pl \\ (D) orcid.org/0000-0002-5778-8420
}

\begin{abstract}
Abstrakt
Motywacja: Motywacją do podjęcia tematu było spostrzeżenie występowania pośród polskich przedsiębiorstw licznych kooperacji z zagranicznymi rywalami, przy równoczesnym zachowaniu postaw konkurencyjnych względem siebie. Tym samym, przedsiębiorstwa krajowe decydują się na stworzenie powiązań koopetycji ze swoimi konkurentami zagranicznymi, których celem jest wejście na rynki obecnie zajmowane przez krajowych producentów. Szczególną uwagę poświęcono internacjonalizacji realizowanej przy użyciu strategii glokalizacji, której przyczyną są wspomniane porozumienia koopetycyjne.

Cel: Celem artykułu jest identyfikacja zjawisk koopetycji jako dominującego narzędzia w implementacji strategii glokalizacji w internacjonalizacji przedsiębiorstw w Polsce. Ponadto, celem szczegółowym jest dokonanie analizy porównawczej różnych strategii internacjonalizacji, ze szczególnym uwzględnieniem glokalizacji, w celu określenia możliwych skutków dla uczestników rynków, na których wdrożono te strategie.

Materiały i metody: Metody rozwiązania problemu podzielono na dwie części: przeglądową oraz jakościową. W pierwszej części dokonano przeglądu dotychczasowego dorobku naukowego w zakresie głównych problemów poruszanych w toku pracy. Głównymi z zastosowanych metod są krytyka piśmiennictwa oraz klaryfikacją pojęć przy użyciu licznych metaanaliz do opisywanego tematu. W części jakościowej przedstawiono przeprowadzone badanie własne dziesięciu branż pod kątem występowania jednej z trzech strategii internacjonalizacji oraz moźliwej współpracy konkurentów między sobą. Źródłem materiałów są obserwacje własne autora, metaanalizy pochodzące z anglojęzycznych czasopism naukowych, doniesienia prasowe, a także oficjalne komunikaty spółek.

Wyniki: W konkluzji stwierdzono przede wszystkim, że koopetycja może być dominującym narzędziem dla przedsiębiorstw zagranicznych, w celu realizacji strategii glokalizacji w różnych branżach w Polsce. Ponadto, można zaobserwować istotne różnice między efektem końcowym implementacji poszczególnych strategii internacjonalizacji przedsiębiorstw.
\end{abstract}

Stowa kluczowe: koopetycja; glokalizacja; globalizacja; internacjonalizacja; strategia przedsiębiorstwa JEL: L14; L10; L21; D40

1. Wprowadzenie

Większość przedsiębiorstw w swoim cyklu życia organizacji spotyka się z sytuacją, w której tempo wzrostu jest niezadowalające i koniecz- nym staje się znalezienie nowych sposobów na jego intensyfikację. Nauki o zarządzaniu oraz nauki ekonomiczne dostarczają przedsiębiorcom narzędzi do kreacji tych sposobów przez szereg różnorodnych koncepcji stra- 
tegii biznesowych (Chrisman i in., 1988, ss. 413-428; Peng, 2000, ss. 15-20). Celem każdej strategii jest dostarczenie informacji o tym, jak efektywniej prowadzić przedsiębiorstwo (Drucker, 1955, ss. 115-126). Jednak, w obliczu mnogości doświadczeń teoretycznych oraz praktycznych, efektywność może być rozumiana na wiele sposobów, m.in w ujęciu: przychodowym, produkcyjnym, wartości dodanej, wielkości kluczowych wskaźników, bądź też bazy klientów (Jarzabkowski, 2005, ss. 29-31). W niniejszym artykule analizowano te koncepcje strategii biznesowych, które zakładają zwiększenie efektywności działania $\mathrm{w}$ dziedzinach kreacji nowych wartości dodanych oraz powiększenia przychodów przez internacjonalizację przedsiębiorstwa, czyli wprowadzenie swoich produktów na rynki zagraniczne, względem rynku macierzystego. W centrum zainteresowania postawiono szczegółową koncepcję strategii biznesowej koopetycji zakładającej, że co najmniej dwóch konkurentów współpracuje ze sobą w pewnych elementach łańcucha produkcji (wartości), równocześnie rywalizując $w$ innych, najczęściej blisko klienta końcowego. Dokonano przeglądu możliwych implementacji tej strategii w kontekście specyficznego sposobu internacjonalizacji przedsiębiorstwa, jakim jest glokalizacja. Łączy ona cechy typowych antagonistycznych sposobów umiędzynarodowienia przedsiębiorstw: regionalizacji oraz globalizacji. W języku polskim oksymoron glokalizacja utworzono $z$ połączenia dwóch przeciwstawnych słów: globalizacji oraz lokalizacji i oznacza adaptację globalnych działań do lokalnych warunków. Termin ten wywodzi się pierwotnie $z$ Japonii, będąc następnie rozpropagowanym przez socjologa R. Robertsona (1995, ss. 25-44) i równocześnie niejako pominiętym przez badaczy europejskich, $w$ tym również polskich. W związku z tym, celem artykułu jest wypełnienie wspomnianej luki badawczej przez identyfikację zjawisk koopetycji jako dominującego narzędzia $w$ implementacji strategii glokalizacji podczas procesów internacjonalizacji przedsiębiorstw $\mathrm{w}$ Polsce. Ponadto, celem szczegółowym jest dokonanie analizy porównawczej różnych strategii inter- nacjonalizacji, ze szczególnym uwzględnieniem glokalizacji, w celu określenia możliwych skutków dla uczestników rynków, na których wdrożono te strategie.

W sekcji 2. dokonano przeglądu dotychczasowego dorobku naukowego w zakresie głównych problemów poruszanych $\mathrm{w}$ toku pracy. W sekcji 3. opisano wykorzystane materiały i metody. W sekcji 4. przedstawiono otrzymane wyniki, natomiast $w$ sekcji 5 . zawarto podsumowanie przeprowadzonej analizy.

\section{Przegląd literatury}

Poprawna metodologicznie analiza postawionego problemu powinna być poprzedzona przedstawieniem dotychczasowych ustaleń nauki $\mathrm{w}$ dziedzinie strategii biznesowych koopetycji i jej implementacji w internacjonalizacji przedsiębiorstw. Ważne jest również wykazanie istotnych różnic między koopetycją a innymi formami współpracy konkurentów między sobą. Natomiast, aby określić czy $\mathrm{w}$ danym przypadku zastosowano koopetycję do umiędzynarodowienia przez glokalizację, przedstawiono również typowe różnice między sposobami internacjonalizacji przedsiębiorstw. Dotychczasowe badania łączące te dwa zagadnienia $w$ zdecydowanej mierze skupiają się jedynie na określeniu związków przyczynowo-skutkowych między możliwością wystąpienia internacjonalizacji w wyniku zastosowania koopetycji między rywalami. W badaniach tych dostrzeżono jednak istotną lukę polegającą na braku dostatecznych deliberacji na temat konkretnego sposobu internacjonalizacji przez koopetycje, czyli czy jest to globalizacja, regionalizacja, bądź też glokalizacja. Zatem, obecne wyniki badań pozwalają odpowiedzieć głównie na pytanie o to, czy koopetycja wpływa na internacjonalizację przedsiębiorstw, zaś nie odpowiadają na pytanie o to, $\mathrm{w}$ jaki sposób przedsiębiorstwa wchodzą na rynki zagraniczne przez koopetycję. Co więcej, samo pojęcie glokalizacji jest zagadnieniem niewystarczająco opisanym $w$ literaturze, czego efektem jest niejednokrotne przypisywanie cech porozumień między 
przedsiębiorstwami jako dowód na regionalizację, bądź na odwrót, globalizację. W celu zmniejszenia tego dysonansu poznawczego, dokonano również wyszczególnienia cech samej glokalizacji, w tym zwłaszcza jej efektów dla przedsiębiorstw, branży i konsumentów.

\subsection{Strategia koopetycji}

Pierwszą zanotowaną w literaturze wzmianką na temat strategii koopetycji w biznesie, a także użycie tego terminu, są przypisywane R. Noordie, kiedy pracował $w$ przedsiębiorstwie Novell w latach 80. (Walley, 2007, ss. 11-31). Opisywał on współpracę między przedsiębiorstwami Novell oraz 3Com jako sojusz między dwoma konkurentami technologicznymi, którego zadaniem było opracowanie wspólnych standardów swoich produktów w celu dodatkowego rozwoju rynku (Bouncken $\mathrm{i}$ in., 2015, ss. 577-601). W ciągu kolejnych lat koncepcja ta ewoluowała w dziedzinie teorii gier, chcąc wyjaśnić jak w wyniku współpracy dwóch konkurentów może powstawać dodatkowa wartość (surplus). Przełomowymi badaniami $w$ tym zakresie okazały się te zaprezentowane przez A. Brandenburgera i B. Nalebuffa (1996), które doprowadzily ich do książkowego bestsellera oraz szeroko cytowanych publikacji. Ich badania nad tematem koopetycji opierały się o teorię gier wartościowych, w której gracze dążą do stworzenia większego rozmiaru rynku przez współpracę, w celu zwiększenia korzyści dla wszystkich graczy zaangażowanych w partnerstwo, a następnie podzielenia większego rynku między graczy przez konkurowanie. Tym samym, rywale decydują się na współpracę w części intensyfikacji popytu, jednocześnie konkurując w części podziału podaży rozumianej jako wartość sprzedaży produktów. Przez autorów licznych metaanaliz powyższa teoria została nazwana actor school of thought ze względu na dużą koncentrację na graczach (aktorach), a nie na działaniach (acting). Koncepcję o nieco odmiennym podejściu przedstawili natomiast M. Bengtsson i S. Cock (2000, ss. 411-426), którzy zaprezentowali wyniki no- wych badań praktycznych nad koopetycją, które to zbiorczo zostały zagregowane do pojęcia activity school of thought. W ich rozumieniu, koopetycja jest relacją diadyczną i naprzeciwległą między parą przedsiębiorstw, co oznacza, że współpracują one $w$ działaniach „z dala” od swoich klientów, jednocześnie konkurując w działaniach „bliskich” klientom. Co więcej, pojawiły się różne dyskusje z perspektywy obu szkół, w wyniku których powstało co najmniej dwadzieścia nowych definicji i setki dowodów empirycznych (Bengtsson i Raza-Ullah, 2016, ss. 23-39; Gnyawali i Charleton, 2018, ss. 2511-2534; Ritala, 2012, ss. 307-324). Dokonując jednak uściślenia oraz agregacji tych definicji, warto przytoczyć jedne z najnowszych, szeroko cytowanych badań nad actor school of thought, tj. pracę S.D. Pathak i in. (2014, ss. 254-267). $Z$ ich perspektywy, przedsiębiorstwa (aktorzy) współpracują we wspólnej sieci dostaw, gdzie rozwijane są strategiczne gry relacyjne, dzięki którym może zachodzić jednoczesna współpraca oraz konkurencja między rywalami. Względna siła konkurentów w sieci wpływa docelowo na poziomy współpracy oraz rywalizacji między nim. Znacznie więcej użytecznych badań, z punktu widzenia niniejszego artykułu, przeprowadzono na bazie rzeczywistych przypadków branżowych, opisanych na kanwie podejścia activity school of thought. Zbliżone teorie i definicje określają koopetycję jako strategię umożliwiającą jednoczesną współpracę i konkurencję między dwoma (lub więcej) przedsiębiorstwami, mającymi na celu stworzenie produktu bardziej wartościowego $z$ perspektywy oceny klienta (Fernandez i in., 2014, ss. 222-235; Gnyawali i Park, 2011, ss. 650-663; Ho i Ganesan, 2013, ss. 91-107; Raza-Ullah i in., 2014, ss. 189198). Efektem implementacji tej strategii mają być zwiększone przychody dla każdego współpracującego rywala, w porównaniu ze strategią opartą wyłącznie na konkurencji (Ritala, 2012, ss. 307-324). W odniesieniu do przedstawionych podejść przyjęto, że ilekroć w niniejszej pracy używa się terminu „koopetycja”, należy go rozumieć jako strategię biznesową, opisaną w ramach activity school of thought. 


\subsection{Koopetycja pośród partnerskich form rywalizacji przedsiębiorstw}

Koncepcja koopetycji należy do zbioru strategii kooperacyjnych między przedsiębiorstwami. Oprócz niej, istnieje jeszcze kilka innych form współzależności między przedsiębiorstwami konkurencyjnymi. Dlatego też, w celu klaryfikacji, należy wykazać istotne różnice między nimi. W sekcji 2.2. porównano koopetycję do takich form współpracy między przedsiębiorstwami, jak: porozumienie o współpracy, alians strategiczny oraz fuzja. W przypadku pierwszej, przedsiębiorstwa mogą zawrzeć ze sobą prostą umowę o współpracy $\mathrm{w}$ dowolnym segmencie swojej działalności, np. w zakresie wspólnych badań i rozwoju, logistyki, produkcji, zachowując przy tym w pełni swoją tożsamość jako marka (Gnyawali i Charleton, 2018, ss. 2511-2534). Ten rodzaj współpracy może ewoluować w bardziej złożonych kierunkach tworząc oddzielną jednostkę joint-venture, która wnosi wartość dodaną dla obu stron umowy. W takim wypadku, otrzymuje się szerszą formułę porozumienia o współpracy, którą nazywa się udziałowym aliansem strategicznym (Varadarajan i Cunningham, 1995, ss. 282-296). Jednak, spółka joint-venture to nie jedyny rodzaj aliansu. Innymi najczęściej przytaczanymi w literaturze wariantami aliansu są: kapitałowy alians strategiczny, outsourcing lub licencjonowanie produktów (Das i Teng, 2000, ss. 31-61; Galloway i in., 2017, ss. 55-65). Stąd też, większość aliansów opiera się o zaangażowanie kapitałowe zrzeszonych podmiotów, w celu kreacji dodatkowej wartości. Cecha ta, wraz z niejednokrotnie zatraceniem osobowości prawnej przedsiębiorstw zrzeszonych, istotnie odróżnia alians od koopetycji. Na tej podstawie, alians można zdefiniować jako międzyorganizacyjną strategię współpracy, która łączy określone zasoby, umiejętności oraz kapitał wszystkich uczestników, w celu osiągnięcia wspólnych celów, a także celów specyficznych dla poszczególnych partnerów (Varadarajan i Cunningham, 1995, ss. 282-296). Z kolei, gdy współpraca typu aliansowego wymaga znacznych nakładów kapitałowych, lub konieczne jest stworzenie „mniej ryzykownej więzi”, może nastąpić fuzja (merger), czyli całościowe połączenie przedsiębiorstw ze sobą $w$ jedną organizację (Antelo i Peón, 2019, ss. 263-279; Das i Teng, 2000, ss. 31-61). Ten rodzaj partnerstwa strategicznego jest ostatnim etapem współpracy między dwoma, lub większą liczbą konkurentów, gdyż przez fuzję rywalizacja między tymi podmiotami całkowicie ustaje. $\mathrm{W}$ rezultacie, połączone przedsiębiorstwa łączą swoje zasoby, a także bazę klientów (udział w rynku), w jedną jednostkę biznesową. Przytoczone definicje kooperatywnych form współpracy można porównać $z$ tytułową koopetycją. Cechą wspólną wszystkich tych porozumień jest niewątpliwie fakt, że konkurencja jest ograniczana, bądź nawet zatracana. W przypadku koopetycji, zawsze najbardziej dochodowa czesść biznesu, czyli ta, odpowiedzialna za sprzedaż produktów, jest utrzymywana $\mathrm{w}$ niezmienionym stanie (Bengtsson i Kock, 2014, ss. 180-188). W związku z tym, koopetycja nie może być realizowana $\mathrm{w}$ formie jakiegokolwiek aliansu, fuzji, przejęcia, bądź wspólnej spółki, ze względu na wzajemne wykluczanie się rywalizacji i współpracy (Antelo i Peón, 2019, ss. 263-279; Bouncken i in., 2016, ss. 77-90). Dlatego też, każdorazowo, gdy przedsiębiorstwa decydują się na utworzenie nowego podmiotu $z$ jednym akcjonariatem, lub strukturą własności, aby konkurować na dotychczasowym rynku, nie należy utożsamiać takiej współpracy z koopetycją lecz bardziej ze strategią pełnej współpracy lub strategicznej zmowy (Gnyawali i Charleton, 2018, ss. 2511-2534; Grimm i in., 2006; Hamel, 1991, ss. 83-103). Jednak, od strony prawnej, koopetycja może istnieć $\mathrm{w}$ wielu formach współpracy takich, jak alianse, umowy o partnerstwie lub dodatkowej spółce, pod warunkiem, że takie partnerstwo utrzyma pewną intensywność konkurencji, w szczególności przez brak zaangażowania kapitału akcyjnego w spółkach macierzystych (Bouncken i in., 2016, ss. 77-90). 


\subsection{Strategie internacjonalizacji przedsiębiorstw}

Podstawowym warunkiem wdrożenia przez przedsiębiorstwa strategii internacjonalizacji (umiędzynarodowienia) jest konieczność poszukiwania nowych rynków zbytu, kreacji innowacji, bądź też poszukiwania nowych pomysłów. Wejście na rynki zagraniczne ma nieść ze sobą wysoką szansę uzyskania dodatkowych przewag konkurencyjnych (Glinkowska i Kaczmarek, 2016, ss. 15-20). Zatem, strategia internacjonalizacji może być zdefiniowana jako sposób rozszerzenia działalności organizacji przez przejście z rynku krajowego na rynki zagraniczne (Vahlne i Johanson, 1990). Natomiast, konkretne sposoby realizacji tej internacjonalizacji, podzielono na trzy główne kategorie (modele): globalizację, regionalizację oraz glokalizację.

W ramach strategii globalizacyjnych, przedsiębiorstwa decydują się na wejście na rynki zagraniczne z produktem globalnym, czyli niemal niezmiennym pod względem cech użytkowych, przekazu marketingowego i innych właściwości, niezależnie od miejsca jego oferowania. W dobie popularności takich pojęć, jak „makdonaldyzacja”, „westernizacja”, czy korporacji transnarodowych, idei, strategii oraz pomysłów na globalne przedsiębiorstwo jest bardzo wiele. Większość strategii globalizacji opiera się jednak o te same, podstawowe założenia, wypracowane przez T. Levitt'a (1983):

- potrzeby nabywców stają się homogeniczne na całym świecie;

- ludność w różnych państwach jest w stanie poświęcić swoje indywidualne preferencje co do produktów na rzecz standaryzacji, która pozwala na tworzenie wyrobów o wysokiej jakości, oferowanych za relatywnie niską cenę;

- $z$ punktu widzenia producentów, ekonomia skali może być osiągnięta przez globalizację, gdyż realizowana podaż jest niemal identyczna we wszystkich państwach, a co za tym idzie, zunifikowane są produkcja i kanały dystrybucji.

Stąd też, ogólnie koncepcję internacjonalizacji, przez globalizacyjne podejście, można zdefiniować jako oferowanie homogenicznych produktów na wielu rynkach zagranicznych, dostosowanych $\mathrm{w}$ niewielu aspektach takich, jak ceny i język. Cechy użytkowe tych produktów są identyczne (Friedman, 2005; Levitt, 1983; Rymarczyk, 2004, ss. 12-16; Stiglitz, 2004 , ss. 23-31). Jest to odpowiedź na proces upodabniania się gustów ludzi na całym świecie. W efekcie, popyt krajowy zaspokajany jest produktem globalnym, a nie lokalnym.

Przeciwstawnym podejściem do globalizacyjnego jest regionalizacja, nazywana też lokalizacją. Według tej strategii, przedsiębiorstwa chcące wejść na rynki zagraniczne, powinny dostosować swój produkt niemal całkowicie do danego państwa, a nawet regionu, w oparciu o preferencje konsumentów istniejące w tym regionie. Głównym założeniem regionalizacji jest przypuszczenie o różnorodności preferencji konsumentów, w zależności od regionu, w którym żyją. Źródłem tych różnic mogą być m.in.: kultura regionu, przyzwyczajenia ludności, bądź też dotychczasowa działalność konkurentów krajowych, do których konsumenci są przywiązani (Hansen, 2002, s. 15; Kotler i Armstrong, 2015, ss. 128-131; Robertson, 1995, ss. 25-44; Steenkamp i De Jong, 2010, ss. 18-40). Według tych autorów, proces strategii lokalizacji rozpoczyna się od odrzucenia przez dane społeczeństwo wzorców globalnych, aby następnie przyjąć wzorce lokalne, czyli spójne kulturowo. Strategia ta zakłada, że w pewnych państwach niemożliwym jest zastosowanie tego samego produktu globalnego, gdyż konsumenci nie są w stanie przyjąć tych samych wartości, co reszta świata, w takim stopniu, aby było to przedsięwzięcie opłacalne dla przedsiębiorstw (Alden $\mathrm{i}$ in., 2006, ss. 227-239).

Regionalizacja jest bardzo często mylona ze strategią hybrydową glokalizacji, która łączy cechy produktu globalnego i lokalnego dostosowania kulturowego. Koncepcja ta jest wciąż bardzo słabo opisana $\mathrm{w}$ literaturze przedmiotu. Powodem tego jest prawdopodobnie stosowanie podejścia antagonistycznego przez badaczy, w którym przedsiębiorstwa dostosowujące coś do warunków lokalnych określa się jako stosujące „regionalizację”, natomiast 
te, które oferują produkty w wielu państwach, jako stosujące "globalizację" (Słodowa-Hełpa, 2017, ss. 7-22). W ujęciu ekonomicznym, glokalizacja rozumiana jest jako lokalna adaptacja produktu, zaprojektowanego jako globalny, w celu zwiększenia wartości dla klienta końcowego na regionalnym rynku, dzięki uwzględnieniu regionalnych wartości kulturowych $\mathrm{w}$ procesie jego produkcji (Alden i in., 2006, ss. 227-239; Ritzer, 2003, ss. 193-209; Robertson, 1995, ss. 25-44).

Inny punkt widzenia na koncepcję glokalizacji, użyteczny w kontekście tytułowych rozważań nad koopetycją, przedstawiają Y. Wong (2002, ss. 152-162) oraz S.P. Douglas i Y. Wind (1987, ss. 19-29), którzy wprost wskazali, że proces lokalnego dostosowania globalnego produktu realizowany jest przez współpracę $z$ lokalnymi konkurentami. Zatem, według tych badaczy, to koopetycja zagranicznego konkurenta $z$ lokalnym rywalem jest nośnikiem produktu globalnego, dostosowanego do rynku lokalnego. Wskazują oni, że każde globalne przedsiębiorstwo może być lokalne $\mathrm{w}$ różnym stopniu, dostosowując takie aspekty, jak: badania i rozwój, łańcuch wartości, portfolio produktowe, bądź procesy biznesowe. Globalizacja, jak wspomniano, do uzyskania sukcesu $\mathrm{w}$ internacjonalizacji przedsiębiorstwa wymaga elastyczności kulturowej poszczególnych narodów, gdzie wzorce globalne są w stanie przeniknąć do lokalnych warunków, w konsekwencji generując dodatkowy przychód na tych rynkach. $Z$ drugiej strony, w ramach rosnącej popularności regionalizacji, regiony starają się chronić i utrzymywać swoją lokalną kulturę, przyzwyczajenia oraz sposoby postępowania, opierając się niejako siłom globalizacji. Stąd też, przedsiębiorstwa, przez glokalizację, próbują zrównoważyć oba te podejścia pod względem zaspokajania lokalnych gustów i preferencji, jednocześnie próbując podążać za globalną strategią rozwoju i wizji przedsiębiorstwa. Kluczowym, strategicznym pytaniem dla przedsiębiorstwa jest jednak określenie, jakiej strategii internacjonalizacji należy użyć na danym rynku zagranicznym, chcąc osiągnąć pożądany efekt. Czy muszą one zastosować strategię lokalną, glokalną, lub też czy powinni kontynuować jednolitą globalną strategię? Dalsza analiza empiryczna poszczególnych branż i zastosowanych na nich strategii internacjonalizacji ma dostarczyć odpowiedzi na te pytania.

\section{Materiały i metody}

Rozważania oparto na dwóch sekcjach metod rozwiązania problemu: przeglądowej oraz jakościowej. W pierwszej $z$ nich, zawartej w sekcji 2., dokonano przeglądu dotychczasowego dorobku naukowego w zakresie głównych problemów poruszanych w toku pracy. W efekcie, uzyskano klaryfikację pojęć oraz metaanalizę przedstawionego problemu. Poszukiwano również luk badawczych w przeprowadzonych $w$ przeszłości badaniach nad koopetycja jako strategią internacjonalizacji przedsiębiorstw. W celu wypełnienia tych luk, w części jakościowej przedstawiono wyniki przeprowadzonego badania własnego dziesięciu branż pod kątem występowania jednej $z$ trzech strategii internacjonalizacji oraz możliwej współpracy konkurentów między sobą. Źródłem materiałów są obserwacje własne autora, metaanalizy pochodzące $z$ anglojęzycznych czasopism naukowych, doniesienia prasowe, a także oficjalne komunikaty spółek.

W tabeli 1. przedstawiono wyniki badania własnego, wykonanego przy użyciu metody porównawczej i metody obserwacji dla celowego doboru zmiennych. Pierwszym etapem badania była identyfikacja trzech najczęściej stosowanych strategii internacjonalizacji przez przedsiębiorstwa wchodzące ze swoimi produktami na istniejące już rynki właściwe w Polsce. Wyszczególniono trzy strategie: globalizacji, regionalizacji oraz glokalizacji, aby w dalszym kroku określić sposób ich realizacji poddawany analizie. W związku z tym, w badaniu uwzględniono przedsiębiorstwa, które zastosowały następujące narzędzia, odpowiadające poszczególnej strategii:

- globalizacja i regionalizacja: bezpośrednie wejście lub licencjonowanie;

- glokalizacja: koopetycja.

$\mathrm{Na}$ podstawie przyjętych założeń, określono następnie możliwie wysoką liczbę 
różnych od siebie branż, istotnie porównywalnych w badaniu jakościowym. W każdej $z$ nich, w kilkuletnim odstępie czasu, wystąpiły wszystkie trzy rodzaje strategii internacjonalizacji oraz narzędzia ich realizacji. Okres czasowy między wystąpieniem każdej zmiennej przyjęto jako maksymalnie równy 10 lat. Celem uściślenia analizy, pominięto wyniki dla określonych strategii inne niż poddawane obserwacji narzędzia realizacji strategii. Oznacza to, że mogły występować inne narzędzia realizacji tytułowej strategii glokalizacji, niż koopetycja. Jednak, cel badania nie zakładał obserwacji strategii glokalizacji, jako ogółu, lecz jako szczegółu, czyli możliwości występowania narzędzia koopetycji w jej realizacji i wynikających z tego skutków.

Kolejne kroki analizy porównawczej oraz przebieg procesu kreacji wniosków przedstawiono w tabeli 2. oraz tabeli 3.

\section{Wyniki badania}

Na podstawie pierwszej części badania, będącej metaanalizą przedstawionego problemu badawczego, można stwierdzić, że istnieją silne przesłanki ku temu, aby zjawisko koopetycji mogło być zaimplementowane jako podstawa strategii glokalizacji $w$ internacjonalizacji przedsiębiorstw. W ramach rozważań teoretycznych, przybliżono szereg założeń, dotychczasowych badań, a także warunków do zaistnienia tego zjawiska. W celu potwierdzenia tych wniosków, dokonano analizy wyników empirycznych przedstawionych w kolejnych krokach badania własnego, wyszczególnionych w tabelach 1-3.

W konkluzji stwierdzono po pierwsze, $\dot{z}$ e wszystkie $z$ dobranych celowo branż umożliwiały precyzyjną identyfikację różnych od siebie strategii internacjonalizacji produktów, w tym zwłaszcza tytułowej glokalizacji przez koopetycję rywala zagranicznego z lokalnym. Oznacza to, że te konkretne przykłady potwierdzały możliwość występowania koopetycji jako jedynego (dominującego) narzędzia realizacji strategii glokalizacji przedsiębiorstw w Polsce.
Po drugie, wybrane branże były stosunkowo niejednorodne, co wskazuje na uniwersalność stosowania koopetycji, a więc dostrzeganie przez różne przedsiębiorstwa wartości dodanej w kooperacji ze swoim konkurentem.

Po trzecie, decydowana większość analizowanych koopetycji była oparta o współpracę $\mathrm{w}$ zakresie marketingu, bądź produkcji, pozostawiając rywalizację $\mathrm{w}$ sferze sprzedaży tych samych produktów, bądź pod zmienioną marką.

Po czwarte, prawdopodobnym motywem koncernów zagranicznych do nawiązania koopetycji $z$ polskimi przedsiębiorstwami była chęć uzyskania dostępu do niektórych przewag konkurencyjnych lokalnego rywala, których źródłem były takie wartości, jak: tradycja, doświadczenie, znajomość rynków, rozpoznawalność.

Po piąte, $w$ przedstawionych strategiach internacjonalizacji przedsiębiorstw można dostrzec, że ich efektem końcowym, rozumianym jako subiektywnie odbierana jakość produktu, to strategia globalizacji cechowała się jego najwyższym stopniem. Średnią jakość zaobserwowano $\mathrm{w}$ strategiach glokalizacji (przez koopetycję), natomiast zdecydowanie najniższej jakości były produkty oferowane w strategiach regionalizacji, czyli dostosowanych lokalnie.

Po szóste, w kategoriach cenowych zaobserwowano prawdopodobną korelacja między jakością a ceną produktów. Oznacza to, że produkty globalne są relatywnie drogie, przy wysokim poziomie jakości, a produkty lokalne były relatywnie tanie, dla niskiego poziomu jakości. Natomiast te, oferowane w powiązaniach koopetycyjnych, były średniej jakości o średniej cenie rynkowej.

Po siódme, w ramach strategii glokalizacji można zauważyć częste występowanie procesu silnego dostosowania produktu globalnego do rynku lokalnego właśnie za sprawą zastosowania koopetycji. Przedsiębiorstwa zagraniczne niejednokrotnie częściowo przejmowały te sekcje łańcucha wartości swojego konkurenta lokalnego, które decydują o jego szczególnej wartości dla konsumentów lokalnych. 
$\mathrm{Na}$ podstawie otrzymanych wyników należy przyjąć, że koopetycja może być dominującym narzędziem dla przedsiębiorstw zagranicznych, w celu realizacji strategii glokalizacji $w$ różnych branżach $w$ Polsce. Ponadto, można zaobserwować istotne różnice między efektem końcowym implementacji poszczególnych strategii internacjonalizacji przedsiębiorstw. Jednak, w toku rozważań przyjęto, że strategia glokalizacji przez koopetycję, wydaje się uśredniać zmienne poddane obserwacji, czyli pozwala zachować balans między pozytywnymi i negatywnymi skutkami dwóch przeciwstawnych strategii, jakimi są globalizacja i regionalizacja.

\section{Zakończenie}

Internacjonalizacja przedsiębiorstw jest tematem nieustannych burzliwych dyskusji, zwłaszcza w kontekście globalizacji i jej możliwych, negatywnych skutkach dla branż i społeczeństw. Niniejszy artykuł miał na celu przybliżyć poznanie niuansów decyzyjnych $\mathrm{w}$ wyborze strategii internacjonalizacji, a tym samym pozwala dokładniej określić przyczyny i skutki każdej z nich. Szczególną uwagę skupiono na specyficznej strategii glokalizacji, która w swych założeniach ma łagodzić negatywne skutki globalizacji, przez przejęcie przez przedsiębiorstwa pozytywnych cech regionalizacji. Jest to jednak strategia niestandardowa, gdyż, jak przedstawiono $w$ badaniu własnym, może nieść ze sobą konieczność kooperacji ze swoim konkurentem lokalnym. Tego typu powiązania niewątpliwie są ryzykowne dla obydwóch stron, a także dla innych uczestników rynków. Jednak, analizowane przedsiębiorstwa zastosowały jednak tę strategię $z$ rynkowym sukcesem, który dowodzi pozytywnych efektów stosowania glokalizacji przez powiązania koopetycyjne.

Wnioski płynące $z$ przeprowadzonego badania mogą być użyteczne zarówno dla decydentów w umiędzynarodowionych przedsiębiorstwach, jak i dla władz samorządowych kreujących strategię polityki regionalnej. Strategia glokalizacji może być obopólną szansą dla przedsiębiorstw i przedstawicieli władzy do pogodzenia niejednokrotnie sprzecznych interesów lokalnych konsumentów i globalnych korporacji.

Identyfikacja tych zjawisk stanowi dobry punkt wyjścia do dalszych badań nad zagadnieniami glokalizacji, nie tylko na przykładzie branż w Polsce, ale i na świecie.

\section{Bibliografia}

Alden, D.L., Steenkamp, J.-B.E.M., i Batra, R. (2006). Consumer attitudes toward marketplace globalization: structure, antecedents and consequences. International Journal of Research in Marketing, 23(3). doi:10.1016/j. ijresmar.2006.01.010.

Antelo, M., i Peón, D. (2019). On cooperation through alliances and mergers. Journal of Industry, Competition and Trade. 19(2). doi:10.1007/ s10842-018-0289-0.

Bengtsson, M., i Kock, S. (2000). 'Coopetition' in business networks: to cooperate and compete simultaneously. Industrial Marketing Management, 29(5). doi:10.1016/S0019-8501(99)00067-X.

Bengtsson, M., i Kock, S. (2014). Coopetition: quo vadis? Past accomplishments and future challenges. Industrial Marketing Management, 43(2). doi:10.1016/j.indmarman.2014.02.015.

Bengtsson, M., i Raza-Ullah, T. (2016). A systematic review of research on coopetition: toward a multilevel understanding. Industrial Marketing Management, 57. doi:10.1016/j. indmarman.2016.05.003.

Bouncken, R.B., Clauß, T., i Fredrich, V. (2016). Product innovation through coopetition in alliances: singular or plural governance? Industrial Marketing Management, 53. doi:10.1016/j. indmarman.2015.11.011.

Bouncken, R.B., Gast, J., Kraus, S., i Bogers, M. (2015). Coopetition: a systematic review, synthesis, and future research directions. Review of Managerial Science, 9(3). doi:10.1007/ s11846-015-0168-6.

Brandenburger, A., i Nalebuff, B. (1996). Co-opetition. New York: Doubleday.

Chrisman, J.J., Hofer, C.W., i Boulton, W.B. (1988). Toward a system for classifying business strategies. Academy of Management Review, 13(3). doi:10.5465/amr.1988.4306963.

Das, T.K., i Teng, B.-S. (2000). A resource-based theory of strategic alliances. Journal of Management, 26(1). doi:10.1177/014920630002600105. 
Douglas, S.P., i Wind, Y. (1987). The myth of globalization. Columbia Journal of World Business, 22(4).

Drucker, P.F. (1955). 'Management science' and the manager. Management Science, 1(2). doi:10.1287/mnsc.1.2.115.

Fernandez, A.-S., Le Roy, F., i Gnyawali, D.R. (2014). Sources and management of tension in co-opetition case evidence from telecommunications satellites manufacturing in Europe. Industrial Marketing Management, 43(2). doi:10.1016/j. indmarman.2013.11.004.

Friedman, T.L. (2005). The world is flat: a brief history of the twenty-first century. New York: Farrar, Straus and Giroux.

Galloway, T.L., Miller, D.R., Sahaym, A., i Arthurs, J.D. (2017). Exploring the innovation strategies of young firms: corporate venture capital and venture capital impact on alliance innovation strategy. Journal of Business Research, 71. doi:10.1016/j.jbusres.2016.10.017.

Glinkowska, B., i Kaczmarek, B. (2016). Zarzadzanie międzynarodowe $i$ internacjonalizacja przedsiębiorstw: teoria i praktyka. Łódź: Wydawnictwo Uniwersytetu Łódzkiego.

Gnyawali, D.R., i Charleton, T. (2018). Nuances in the interplay of competition and cooperation: towards a theory of coopetition. Journal of Management, 44(7). doi:10.1177/0149206318788945.

Gnyawali, D.R., i Park, B.-J. (2011). Co-opetition between giants: collaboration with competitors for technological innovation. Research Policy, 40(5). doi:10.1016/j.respol.2011.01.009.

Grimm, C.M., Lee, H., i Smith, K.G. (red.). (2006). Strategy as action: competitive dynamics and competitive advantage. Oxford: Oxford University Press.

Hamel, G. (1991). Competition for competence and inter-partner learning within international strategic alliances. Strategic Management Journal, 12(S1). doi:10.1002/smj.4250120908.

Hansen, G.E. (2002). The culture of strangers: globalization, localization, and the phenomenon of exchange. Lanham: University Press of America.

Ho, H., i Ganesan, S. (2013). Does knowledge base compatibility help or hurt knowledge sharing between suppliers in coopetition? The role of customer participation. Journal of Marketing, 77(6). doi:10.1509/jm.11.0570.

Jarzabkowski, P. (2005). Strategy as practice: an activity-based approach. London-Thousand Oaks: Sage.

Kotler, P., i Armstrong, G. (2015). Marketing: wprowadzenie. Warszawa: Wolters Kluwer Business.
Levitt, T. (1983). The globalization of markets. Harvard Business Review, May.

Pathak, S.D., Wu, Z., i Johnston, D. (2014). Toward a structural view of co-opetition in supply networks. Journal of Operations Management, 32(5). doi:10.1016/j.jom.2014.04.001.

Peng, M.W. (2000). Business strategies in transition economies. Thousand Oaks: Sage.

Raza-Ullah, T., Bengtsson, M., i Kock, S. (2014). The coopetition paradox and tension in coopetition at multiple levels. Industrial Marketing Management, 43(2). doi:10.1016/j. indmarman.2013.11.001.

Ritala, P. (2012). Coopetition strategy: when is it successful? Empirical evidence on innovation and market performance. British Journal of Management, 23(3). doi:10.1111/j.1467-8551.2011.00741.x.

Ritzer, G. (2003). Rethinking globalization: glocalization/grobalization and something/nothing. Sociological Theory, 21(3). doi:10.1111/1467-9558.00185.

Robertson, R. (1995). Glocalization: time-space and homogeneity-heterogeneity. W: M. Featherstone, S. Lash, i R. Robertson (red.), Global modernities. London: Sage. doi:10.4135/9781446250563.n2.

Rymarczyk, J. (2004). Internacjonalizacja i globalizacja przedsiębiorstwa. Warszawa: PWE.

Słodowa-Hełpa, M. (2017). Między globalizacją a glokalizacją. Studia Oeconomica Posnaniensia, 5(5). doi:10.18559/SOEP.2017.5.1.

Steenkamp, J.-B.E.M., i De Jong, M.G. (2010). A global investigation into the constellation of consumer attitudes toward global and local products. Journal of Marketing, 74(6). doi:10.1509/ jmkg.74.6.18.

Stiglitz, J.E. (2004). Globalizacja. Warszawa: PWN.

Vahlne, J., i Johanson, J. (1990). The mechanism of internationalisation. International Marketing Review, 7(4). doi:10.1108/02651339010137414.

Varadarajan, P.R., i Cunningham, M.H. (1995). Strategic alliances: a synthesis of conceptual foundations. Journal of the Academy of Marketing Science, 23(4). doi:10.1177/009207039502300408.

Walley, K. (2007). Coopetition: an introduction to the subject and an agenda for research. International Studies of Management and Organization, 37(2). doi:10.2753/IMO0020-8825370201.

Wong, Y. (2002). The coming challenge: an entrepreneurial pathway for the 21st century. W: A. Mahizhnan, i L.T. Yuan (red.), Singapore: re-engineering success. Singapore: Times Academic Press for the Institute of Policy Studies. 
Informacje uzupetniające

Wkład autorski: autor zaakceptował ostateczną wersję artykułu.
Źródła finansowania: artykuł został w całości sfinansowany ze środków własnych autora.

Uwagi: wyniki badania były zaprezentowane na 9. Ogólnopolskiej Konferencji Naukowej Problemy gospodarkiświatowej (10 maja 2019, Toruń). 
Aneks

Tabela 1.

Wejściowe wyniki badania w postaci wykazu przedsiębiorstw, które zastosowały poszczególne strategie internacjonalizacji w wybranych branżach w Polsce

\begin{tabular}{|c|c|c|c|}
\hline \multirow{2}{*}{ Branża } & \multicolumn{3}{|c|}{ Przedsiębiorstwa (marki) stosujące strategię internacjonalizacji } \\
\hline & globalizacji & regionalizacji & glokalizacji \\
\hline produkcja pociągów pasażerskich & Alstom (Pendolino) & Stadler (Flirt) & konsorcjum Stadler/Newag \\
\hline produkcja piwa & Heineken & Carlsberg (Harnaś) & Desperados \\
\hline przewozy pasażerskie & Leo Express & PolskiBus.com & FlixBus \\
\hline programy telewizyjne & CSI kryminalne zagadki & Rodzinka.pl & Milionerzy \\
\hline ustugi restauracyjne & McDonald's & Froneri (Zielona Budka) & $\begin{array}{c}\text { Amrest SA (KFC, Pizza } \\
\text { Hut, Burger King, Star- } \\
\text { bucks) }\end{array}$ \\
\hline produkcja słonych przekasek & Lay's & $\begin{array}{c}\text { Lorenz (Wiejskie Ziem- } \\
\text { niaczki) }\end{array}$ & Lorenz (Lajkonik Krakersy) \\
\hline produkcja słodkich napojów & Coca-Cola & Kofola SA (Hoop Cola) & Pepsi Co. (soki Toma) \\
\hline produkcja sosów pomidorowych & Hellman's & Heinz (Pudliszki) & McCormick (Kamis) \\
\hline produkcja kawy & Nestle (Nescafe) & $\begin{array}{c}\text { Jacobs Douwe (Prima } \\
\text { Finezja) }\end{array}$ & $\begin{array}{c}\text { Strauss Cafe Ltd. (Optima, } \\
\text { Fort) }\end{array}$ \\
\hline produkcja wódki & Smirnoff & Russian Standard (Soplica) & Stock (Żotadkowa Gorzka) \\
\hline
\end{tabular}

Uwagi:

W nawiasach podano marki lub produkty, do których odnosi się analizowany sposób internacjonalizacji.

Źródło: Opracowanie własne. 
Tabela 2.

Analiza porównawcza wejściowych wyników badania w postaci wykazu szczegółowych implementacji strategii internacjonalizacji przez analizowane przedsiębiorstwa

\begin{tabular}{|c|c|c|c|}
\hline \multirow{2}{*}{ Branża } & \multicolumn{3}{|c|}{ Przedsiębiorstwa (marki) stosujące strategię internacjonalizacji } \\
\hline & globalizacji & regionalizacji & glokalizacji \\
\hline $\begin{array}{l}\text { produkcja } \\
\text { pociągów } \\
\text { pasażerskich }\end{array}$ & $\begin{array}{c}\text { dystrybucja niemal identycznego } \\
\text { produktu globalnego (pociagu } \\
\text { Pendolino dla PKP) }\end{array}$ & $\begin{array}{l}\text { produkcja i dystrybucja pociagów } \\
\text { Flirt na specjalne, spersonalizo- } \\
\text { wane zamówienie dla PKP }\end{array}$ & $\begin{array}{c}\text { współpraca lokalnego przedsię- } \\
\text { biorstwa Newag z zagranicznym } \\
\text { konkurentem Stadler nad wspól- } \\
\text { ną produkcją pociągu }\end{array}$ \\
\hline $\begin{array}{l}\text { produ } \\
\text { piwa }\end{array}$ & $\begin{array}{c}\text { produkcja identycznego piwa } \\
\text { Heineken na licencji i dystry- } \\
\text { bucja z taką samą identyfikacją } \\
\text { wizualną }\end{array}$ & $\begin{array}{c}\text { produkcja piwa Harnaś z lokalną } \\
\text { identyfikacją wizualną przez } \\
\text { globalny koncern Carlsberg } \\
\text { na podstawie globalnych receptur } \\
\text { smakowych }\end{array}$ & $\begin{array}{c}\text { wspólpraca Grupy Żywiec } \\
\text { z konkurentem zagranicznym } \\
\text { Heineken w postaci dystrybucji, } \\
\text { logistyki oraz promocji piwa } \\
\text { Desperados na licencji }\end{array}$ \\
\hline $\begin{array}{l}\text { przewozy } \\
\text { pasażerskie }\end{array}$ & $\begin{array}{c}\text { wejście na poszczególne trasy } \\
\text { pasażerskie z identyczną marką, } \\
\text { bez jakichkolwiek dostosowań } \\
\text { lokalnych }\end{array}$ & $\begin{array}{c}\text { wprowadzenie przez Souter } \\
\text { Holding przewozów pasażerskich, } \\
\text { silnie zorientowanych na lokalny } \\
\text { segment nabywców pod marką } \\
\text { PolskiBus.com }\end{array}$ & $\begin{array}{c}\text { koopetycja wielu przewoźników } \\
\text { lokalnych z przedsiębiorstwem } \\
\text { Flixbus w postaci wspólnej } \\
\text { identyfikacji wizualnej oraz } \\
\text { dystrybucji }\end{array}$ \\
\hline $\begin{array}{l}\text { programy } \\
\text { telewizyjne }\end{array}$ & $\begin{array}{l}\text { dystrybucja tego samego serialu } \\
\text { telewizyjnego bez żadnych dosto- } \\
\text { sowań na rynkach lokalnych } \\
\text { (w Polsce) }\end{array}$ & $\begin{array}{l}\text { stworzenie serialu Rodzinka.pl } \\
\text { opartego o licencję kanadyjskiego } \\
\text { Les Parent, właściciela ICI Radio- } \\
\text {-Canada Télé }\end{array}$ & $\begin{array}{l}\text { współpraca lokalnego konkurenta } \\
\text { ITI Television (TVN) z bry- } \\
\text { tyjskim ITV w stworzeniu dosto- } \\
\text { sowanej wersji programu Who } \\
\text { wants to be a millionaire? }\end{array}$ \\
\hline $\begin{array}{l}\text { ustugi restau- } \\
\text { racyjne }\end{array}$ & $\begin{array}{l}\text { oferowanie globalnych produk- } \\
\text { tów restauracyjnych przez markę } \\
\text { McDonald's (obecnie synonimu } \\
\text { globalizacji) }\end{array}$ & $\begin{array}{c}\text { własność dostosowanych lokalnie } \\
\text { kawiarni Zielona Budka po stro- } \\
\text { nie zagranicznej grupy Froneri }\end{array}$ & $\begin{array}{c}\text { koopetycja polskiej grupy Amrest } \\
\text { SA z globalnymi właścicielami } \\
\text { sieci restauracyjnych (KFC, Pizza } \\
\text { Hut, Burger King, Starbucks) } \\
\text { w ramach szerokiego spektrum } \\
\text { lańcucha wartości }\end{array}$ \\
\hline $\begin{array}{l}\text { produkcja } \\
\text { słonych } \\
\text { przekąsek }\end{array}$ & $\begin{array}{l}\text { wprowadzenie identycznych } \\
\text { chipsów marki Lay's w Polsce, } \\
\text { z jedynym dostosowaniem } \\
\text { w postaci języka polskiego } \\
\text { na etykietach }\end{array}$ & $\begin{array}{l}\text { rozwijanie produktów dostoso- } \\
\text { wanych lokalnie przez globalne } \\
\text { przedsiębiorstwo Lorenz (chipsy } \\
\text { Wiejskie Ziemniaczki) na bazie } \\
\text { globalnych receptur smakowych }\end{array}$ & $\begin{array}{l}\text { początkowa koopetycja marki } \\
\text { globalnej Lorenz z lokalnym kon- } \\
\text { kurentem Koncentraty Spożywcze } \\
\text { Skawina zakończona przejęciem } \\
\text { i pozostawieniem produktu } \\
\text { lokalnego przez jeden wspólny } \\
\text { podmiot (Lajkonik Krakersy) }\end{array}$ \\
\hline $\begin{array}{l}\text { produkcja } \\
\text { słodkich } \\
\text { napojów }\end{array}$ & $\begin{array}{l}\text { oferowanie w Polsce przez } \\
\text { globalny koncern Coca-Cola } \\
\text { zunifikowanych produktów, } \\
\text { zarówno pod względem smaku, } \\
\text { jak i pozostałych cech marki } \\
\text { (logo, slogan, reklama) }\end{array}$ & $\begin{array}{l}\text { wprowadzenie na polski rynek } \\
\text { napoju o innych walorach } \\
\text { smakowych, bardziej dostoso- } \\
\text { wanych do preferencji lokalnych } \\
\text { konsumentów (Hoop Cola) przez } \\
\text { przedsiębiorstwo Kofola SA ma- } \\
\text { jące w swoim portfolio głównie } \\
\text { napój typu cola o nazwie Kofola }\end{array}$ & $\begin{array}{l}\text { koopetycja globalnej marki Pepsi } \\
\text { Co.z polskim konkurentem Toma } \\
\text { sp. z o.o. w segmencie soków we } \\
\text { wszystkich częściach łańcucha } \\
\text { wartości (oprócz produkcji), przy } \\
\text { czym obydwa podmioty mogą } \\
\text { sprzedawać produkty niezależnie } \\
\text { od przejęcia praw do marki Toma } \\
\text { przez Pepsi }\end{array}$ \\
\hline
\end{tabular}




\begin{tabular}{|c|c|c|c|}
\hline \multirow{2}{*}{ Branża } & \multicolumn{3}{|c|}{ Przedsiębiorstwa (marki) stosujące strategię internacjonalizacji } \\
\hline & globalizacji & regionalizacji & glokalizacji \\
\hline $\begin{array}{l}\text { produkcja } \\
\text { sosów pomi- } \\
\text { dorowych }\end{array}$ & $\begin{array}{c}\text { oferowanie przez Hellman's swo- } \\
\text { ich sosów pod jednolitą marka, } \\
\text { zarówno pod względem walorów } \\
\text { smakowych, jak i przekazu } \\
\text { marketingowego }\end{array}$ & $\begin{array}{c}\text { własność produktu stylizowanego } \\
\text { na lokalny (ketchupów marki } \\
\text { Pudliszki) po stronie globalnego } \\
\text { przedsiębiorstwa Heinz }\end{array}$ & $\begin{array}{l}\text { kooperacja koncernu McCormick } \\
\text { z polskim przedsiębiorstwem } \\
\text { Kamis w celu rozszerzenia } \\
\text { swojego portfolio produktów } \\
\text { o przyprawy, równocześnie } \\
\text { Kamis zachował podmiotowość } \\
\text { i może konkurować z McCormick }\end{array}$ \\
\hline $\begin{array}{l}\text { produkcja } \\
\text { kawy }\end{array}$ & $\begin{array}{l}\text { oferowanie przez Nestle na całym } \\
\text { świecie (w tym w Polsce) spój- } \\
\text { nych produktów z linii Nescafe }\end{array}$ & $\begin{array}{l}\text { sprzedaż w Polsce przez Jacobs } \\
\text { Douwe mocno spersonalizowa- } \\
\text { nych pod lokalnego konsumenta } \\
\text { produktów na bazie kawy takich, } \\
\text { jak marka Prima Finezja }\end{array}$ & $\begin{array}{l}\text { wspólpraca koncernu Strauss } \\
\text { Cafe Ltd. z producentami pol- } \\
\text { skich kaw takimi, jak Optima, czy } \\
\text { Fort, w segmentach dystrybucji } \\
\text { i zaopatrzenia, będąc równocze- } \\
\text { śnie konkurentem sprzedającym } \\
\text { kawy innych marek (w tym } \\
\text { własnych) }\end{array}$ \\
\hline $\begin{array}{l}\text { produkcja } \\
\text { wódki }\end{array}$ & $\begin{array}{l}\text { oferowanie przez koncern Smir- } \\
\text { noff wódek na polskim rynku } \\
\text { o identycznych wartościach } \\
\text { (w tym wizualnych), co na in- } \\
\text { nych, globalnych rynkach }\end{array}$ & $\begin{array}{l}\text { własność typowego produktu } \\
\text { regionalnego, oferowanego przez } \\
\text { globalnego producenta (m.in. } \\
\text { wódki Soplica) po stronie koncer- } \\
\text { nu Russian Standard }\end{array}$ & $\begin{array}{l}\text { produkcja w Polsce wysoce do- } \\
\text { stosowanego do rynku lokalnego } \\
\text { produktu (wódki Żoładkowej } \\
\text { Gorzkiej) przez przedsiębiorstwo } \\
\text { Stock we współpracy z białostoc- } \\
\text { kim Polmosem, który równocze- } \\
\text { śnie produkuje i sprzedaje innego } \\
\text { rodzaju alkohole pod własnymi } \\
\text { markami }\end{array}$ \\
\hline
\end{tabular}

Uwagi:

Wszystkie kolumny przyporządkowane do wierszy, w których zawarto nazwy branż odpowiadają tym samym kolumnom, widocznym w tabeli 1 . Stąd też, wnioski na temat konkretnych branż i strategii internacjonalizacji odnoszą się do dokładnie sprecyzowanych marek z tabeli 1 .

Cechy użytkowe produktów, w tym porównanie wyglądu, jakości, przekazu marketingowego, były badane na podstawie własnych obserwacji autora, a także za pomocą metod wywiadów oraz informacji w sieci Internet.

W nawiasach podano marki lub produkty, do których odnosi się analizowany sposób internacjonalizacji.

Źródło: Opracowanie własne. 
Tabela 3.

Wyjściowe wyniki badania w postaci najważniejszych efektów dla uczestników rynków jako skutek implementacji poszczególnych strategii internacjonalizacji w wybranych branżach w Polsce

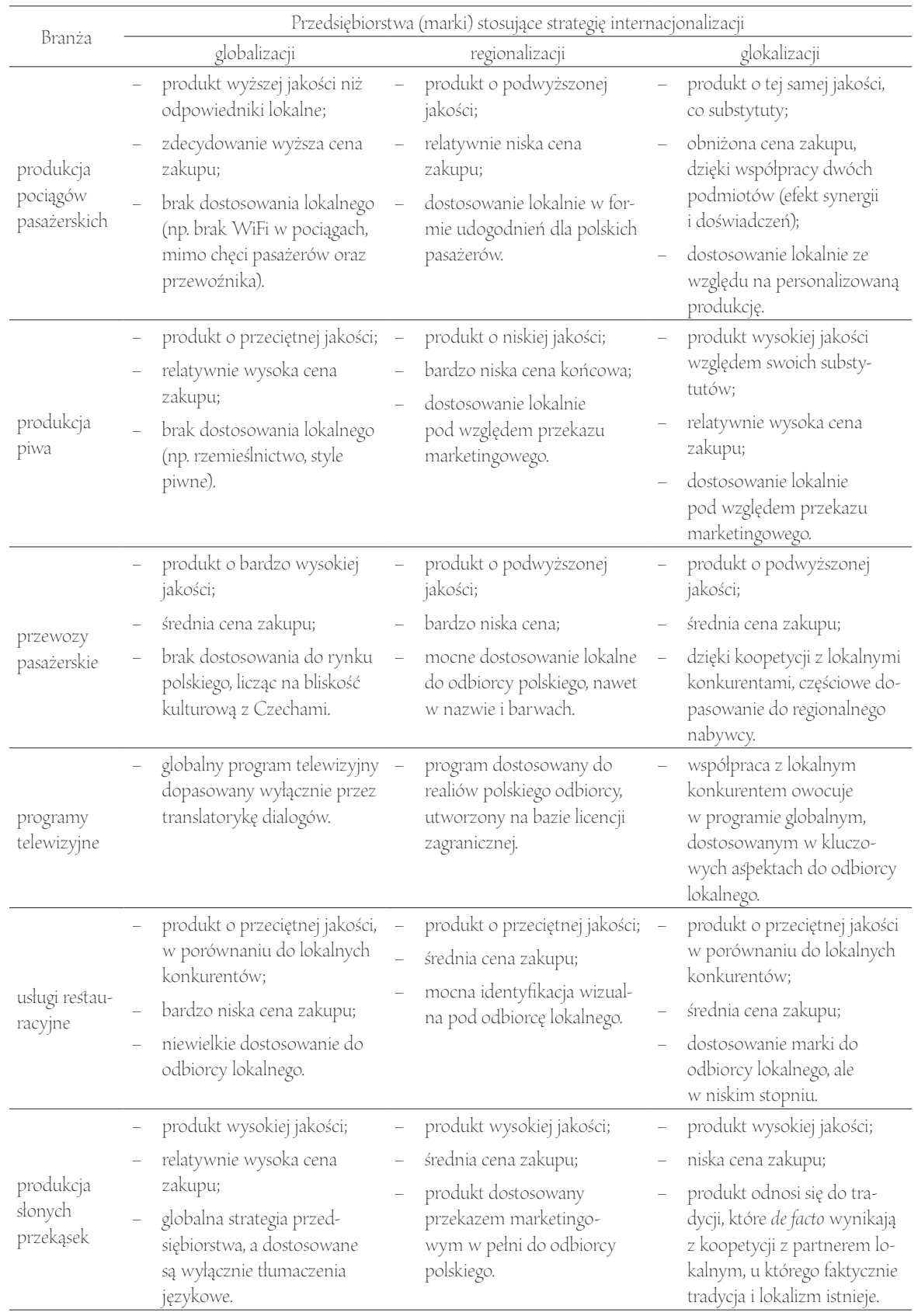




\begin{tabular}{|c|c|c|c|}
\hline \multirow{2}{*}{ Branża } & \multicolumn{3}{|c|}{ Przedsiębiorstwa (marki) stosujące strategię internacjonalizacji } \\
\hline & globalizacji & regionalizacji & glokalizacji \\
\hline $\begin{array}{l}\text { produkcja } \\
\text { słodkich } \\
\text { napojów }\end{array}$ & $\begin{array}{l}\text { _- produkt wysokiej jakości; } \\
\text { _ } \text { relatywnie wysoka cena } \\
\text { zakupu; } \\
\text { _ } \\
\text { strategia internacjonalizacji } \\
\text { wysoce globalna o nikłych } \\
\text { dostosowaniach lokalnych. }\end{array}$ & 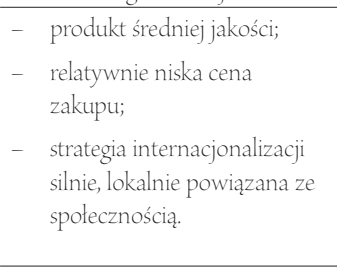 & $\begin{array}{l}\text { __ produkt średniej jakości; } \\
\text { _ } \quad \text { wysoka cena zakupu; } \\
\text { _ } \quad \text { strategia internacjonalizacji } \\
\text { z odniesieniem do lokalnej } \\
\text { tradycji konkurenta lokalne- } \\
\text { go, z którym Pepsi Co. weszło } \\
\text { w koopetycję. }\end{array}$ \\
\hline $\begin{array}{l}\text { produkcja } \\
\text { sosów pomi- } \\
\text { dorowych }\end{array}$ & 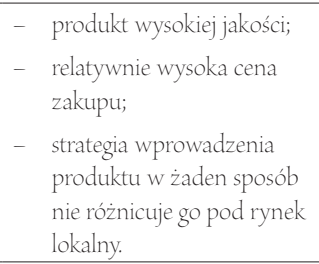 & $\begin{array}{l}\text { - produkt wysokiej jakości; } \\
\text { - średnia cena zakupu; } \\
\text { - produkowany wyłącznie } \\
\text { pod lokalne rynki i ich } \\
\text { odbiorców. }\end{array}$ & $\begin{array}{l}\text { - } \text { produkt wysokiej jakości; } \\
\text { _ } \quad \text { wysoka cena zakupu; } \\
\text { _ } \text { przez pozostawienie sfery } \\
\text { produkcji oraz identyfikacji } \\
\text { wizualnej konkurentowi } \\
\text { lokalnemu, produkt jest wy- } \\
\text { soce dostosowany lokalnie. }\end{array}$ \\
\hline $\begin{array}{l}\text { produkcja } \\
\text { kawy }\end{array}$ & 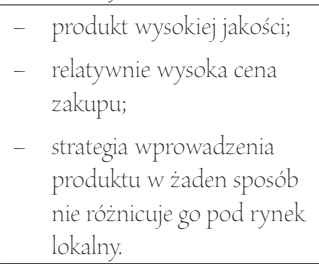 & $\begin{array}{l}\text { - } \\
\text { średnia jakość wyrobu; } \\
\text { _ } \\
\text { średnia cena zakupu; } \\
\text { - } \text { produkt nieustannie } \\
\text { promowany jako lokalny } \\
\text { i dostosowany do warunków } \\
\text { polskiego konsumenta. }\end{array}$ & 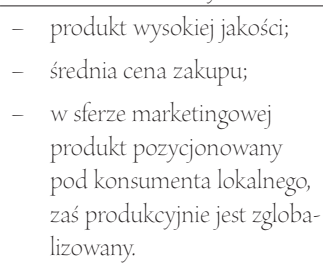 \\
\hline $\begin{array}{l}\text { produkcja } \\
\text { wódki }\end{array}$ & 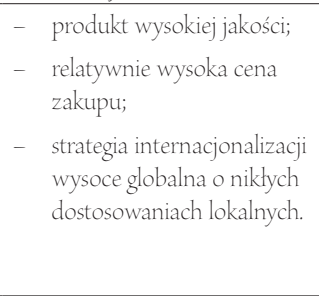 & $\begin{array}{l}\text { _- produkt średniej jakości; } \\
\text { _ } \text { relatywne wysoka cena } \\
\text { zakupu; } \\
\text { _ } \text { produkt reklamowany jako } \\
\text { tradycyjny oraz polski, choć } \\
\text { jest produkowany w sposób } \\
\text { globalny. }\end{array}$ & $\begin{array}{l}\text { - } \quad \text { produkt średniej jakości; } \\
\text { _- niska cena zakupu; } \\
\text { _- dzięki koopetycji z lokalnym } \\
\text { producentem, wyrób nie } \\
\text { różni się jakościowo od } \\
\text { swoich poprzednich wersji, } \\
\text { utrzymano również lokalny } \\
\text { charakter produktu. }\end{array}$ \\
\hline
\end{tabular}

Uwagi:

Wszystkie kolumny przyporządkowane do wierszy, w których zawarto nazwy branż odpowiadają tym samym kolumnom, widocznym w tabeli 1. oraz w tabeli 2. Stąd też, wnioski na temat konkretnych branż i strategii internacjonalizacji odnoszą się do dokładnie sprecyzowanych marek z tabeli 1. oraz sytuacji strategicznych z tabeli 2.

W każdej kolumnie przedstawiono w jednakowy sposób skutki implementacji danej strategii internacjonalizacji dla rynków, przy czym w niektórych przypadkach nie było możliwe określenie tych samych determinantów porównawczych: jakości produktu, poziomu ceny, dostosowania lokalnego.

Źródło: Opracowanie własne. 
Coopetition as a strategy for glocalisation of enterprises in Poland

\begin{abstract}
Motivation: The motivation to address the topic was the observation of numerous cooperation of polish enterprises with foreign competitors with simultaneous existence of competition process between them. Thus, domestic enterprises decide to establish coopetition links with their foreign competitors, the aim of which is to enter the markets currently occupied by domestic producers. Particular attention was paid to the phenomena of internationalization strategies with the focus on glocalisation strategy which is caused by the abovementioned coopetition agreements.

Aim: The aim of the article is to identify coopetition phenomena as the dominant tool in the implementation of the glocalization strategy in the internationalization of enterprises in Poland. In addition, a specific aim is a comparative analysis of various internationalization strategies, with particular emphasis on glocalisation, to identify possible impacts on market participants in which these strategies have been implemented.

Materials and methods: Research methods are divided into two parts: systematic review and study. The first part reviews numerous of meta-analysis in the fields of main problems discussed in the course of the paper. The study part presents own qualitative research that contains the data of ten industries for the occurrence of one of three internationalization strategies and possible cooperation between competitors. The source of the materials are the author's own observations, meta-analysis from worldwide scientific journals, press reports as well as official company announcements. Results: In the conclusion it was primarily stated that coopetition can be the dominant strategy for foreign enterprises in order to implement the strategy of glocalisation in various industries in Poland. Furthermore, significant differences might be observed between the effects of implementing particular internationalization strategies on the example of the analysed enterprises.
\end{abstract}

Keywords: coopetition; glocalisation; globalization; internationalization; business strategy JEL: L14; L10; L21; D40 